JiiP Volume 5 Nomor 1: 1-11, Juni 2019

Jurnal Ilmu dan Industri Peternakan pISSN 2355-0732, eISSN 2716-2222

http://journal.uin-alauddin.ac.id/index.php/jiip/index DOI https:/ / doi.org/10.24252/jiip.v5i1.11098

\title{
Profil Malondialdehyde (MDA) dan Kreatinin Itik Fase Layer yang Diberi Minyak Atsiri Garlic dalam Kondisi Cekaman Panas
}

\author{
Profile of Malondialdehyde (MDA) and Creatinine Ducks Layer Phase Given \\ Garlic Essential Oil in Hot Stress Conditions
}

\author{
A. Mushawwir*, N. Suwarno, A. A. Yulianti \\ Fakultas Peternakan Universitas Padjadjaran \\ Kampus Jatinangor Jl. Raya Bandung-Sumedang Km. 21, Sumedang \\ *Korespondensi Email: mushawwir@unpad.ac.id
}

\begin{abstract}
ABSTRAK
Cekaman panas menyebabkan peningkatan radikal bebas. Radikal bebas mampu mengoksidasi PUFA sehingga kadar MDA bertambah serta menyebabkan pemanfatan sumber energy yaitu kreatin fosfat, untuk mendukung kontraksi otot-otot jantung dan otot terkait respirasi dalam mengevaporasikan panas tubuh itik. Kondisi ini berdampak negatif bagi ternak itik. Untuk itu telah dilakukan penelitian untuk mengetahui efek pemberian minyak atsiri untuk menanggulangi sintesis MDA dan kreatinin pada itik. Empat puluh empat ekor itik cihateup berjenis kelamin betina, berumur 25 bulan telah digunakan, dibagi dua kelompok, masing-masing 22 ekor tidak diberi minyak atsiri dan 22 ekor lainnya diberi minyak atsiri 0.5 $\mathrm{mL} / \mathrm{kg}$ BB per 2 hari. Itik dipelihara selama 2 bulan. Pemberian pakan diatur $215 \mathrm{~g} /$ ekor perhari selama penelitian. Isolasi minyak atsiri dilakukan dengan menggunakan metode penguapan distilasi. Sampel darah dari tiap-tiap ternak dikoleksi pada akhir penelitian, menggunakan tabung venojette ber-EDTA 5 $\mathrm{mL}$. Sampel segera dicentrifuge untuk untuk memperoleh plasma dan hemolisat sel-sel darahnya. Plasma digunakan untuk menganalisis kadar kreatinnya, menggunakan teknik spektrofotometrik mengikuti prosedur kit BIOLABO, France. Hemolisat digunakan untuk menganalisis kadar MDA sampel, dengan teknik spektrofotometrik. Berdasarkan hasil penelitian disimpulkan bahwa minyak atsiri mampu menghambat sintesis malondialdehyde (MDA) dan kreatinin itik cihateup yang mengalami cekaman panas.
\end{abstract}

Kata kunci: Cekaman Panas, Malondialdehide, Kreatinin, Itik

\section{ABSTRACT}

Heat stress caused an increase free radical. Free radicals play a role to attack poly unsaturated fatty acids, have the impact in increasing concentration of MDA and the utilization of creatin phosfat as energy source. These energy used to improve the heart and respiration muscle contraction. This study was conducted to investigation effect of volatile fatty acid (VFA) to avoid MDA and creatinine. Forty four cihateup duck were using in this research, separated to two group, each group consist 22 duck. One group without VFA and the other were added 0.5 mL.BW-1 VFA. Blood sample were collected using EDTA tube $5 \mathrm{~mL}$. Blood plasma using for analyzing creatine, whereas MDA used blood cells. All parameters were analyzed by spectrophotometric fallowing the Biolabo KIT 
Analysis Procedure. Based on the results of this study showed that VFA can be reduction MDA and creatinine of cihateup duck heat stressed. These indicated that VFA plays the role as antioxidant effectively.

Key words: Stress, Malondialdehyde, Creatinin, Duck

\section{PENDAHULUAN}

Temperatur lingkungan di atas kondisi nyaman (upper thermoneutral zone) bagi ternak menyebabkan penurunan secara keseluruhan produktivitas ternak. Fakta ini merupakan konpensasi penggunaan makro dan mikromolekul sebagai precursor energy untuk produksi, beralih menjadi precursor energy untuk homeostasis. Proses homeostasis yang berlangsung dalam jangk panajng menyebabkan terjadinya stres selular.

Stres sellular bukan hanya ditandai dengan meningkatnya senyawa-senyawa radikal terutama dari kelompok reactive oxygen species (ROS), sebagai dampak peningatan oksidasi reduksi (sintesis ATP) dalam mitokondria karena peningkatan gluconeogenesis. Peningkatan ROS menstimulasi oksidasi asam lemak rantai panjang ganda dengan MDA sebagai produk metabolismenya. Selain peningkatan ROS, indikator lain ditunjukkan dengan meningkatnya kadar kreatinin yang bersirkulasi dalam system vaskuler. Peningkatan kadar kreatinin ini merupakan dampak pemanfaatan creatin menjadi kreatianin oleh creatin kinase dan melepaskan 1 mol ATP. Katabolisme ini diperlukan guna mendukung penyediaan energy terkait meningkatnya kontraksi otot-otot pernfasan dan jantung.

Diperlukan upaya untuk mengurangi dampak cekaman panas tersebut. Salah satu strategi yang dapat diaplikasin adalah pemanfaatan minyak atsiri dari garlic. Diketahui bahwa atsiri garlic mengandung setidaknya 14 jenis asam lemak terbang (VFA) dengan komponen terbanyak adalah diallyl disulfide, citronella, diallyl trisulfida. Komponenkomponen minyak atsiri mampu bertindak sebagai natioksidan dan umumnya menstimulasi perbaikan metabolisme. Diharapkan melalui pemberian atsiri pada itik yang mengalami cekaman panas dapat mngurangi kadar MDA dan mencegah penggunaan kreatin yang berlebihan sebagai sumber energy kontraksi otot.

\section{Prosedur Penelitian}

\section{METODE}

Empat pupuh empat ekor itik cihateup berjenis kelamin betina, berumur 25 bulan telah digunakan dalam penelitian ini sebagai ternak sampel. Itik dibagi dua kelompok, masing- 
masing 22 ekor tidak diberi minyak atsiri dan 22 ekor lainnya diberi minyak atsiri $0.5 \mathrm{~mL} / \mathrm{kg}$ BB per 2 hari. Itik dipelihara selama 2 bulan. Pemberian pakan diatur $215 \mathrm{~g} /$ ekor perhari selama penelitian.

\section{Analisis Data}

Isolasi minyak atsiri dilakukan dengan menggunakan metode Guenther (2006) dan Amin dkk. (2014). Sebanyak 4000 gram bawang putih digunakan dalam penelitian ini. Semua sampel diiris halus kemudian dimasukkan ke labu alas bulat (disesuaikan dengan kapasitas labu), lalu tambahkan aquadest sampai seluruh sampel bawang ptuih terendam sempurna di dalam labu alas bulat berleher panjang yang telah dirangkai dalam perangkat alat destilasi air. Destilasi dilakukan selama 4-5 jam. Minyak atsiri yang diperoleh ditampung dalam corong pisah lalu dipisahkan antara minyak dengan air. Minyak atsiri yang diperoleh ditambahkan natrium sulfat anhidrat, dikocok dan didiamkan selama 25-26 jam. Minyak atsiri yang diperoleh kemudian dipipet dan disimpan dalam vial yang bersih.

Sampel darah dari tiap-tiap ternak dikoleksi pada akhir penelitian, menggunakan tabung venojette ber-EDTA $5 \mathrm{~mL}$. Sampel segera dicentrifuge untuk untuk memperoleh plasma dan hemolisat sel-sel darahnya. Plasma digunakan untuk menganalisis kadar kreatinnya, menggunakan teknik spektrofotometrik mengikuti prosedur kit BIOLABO, France (2015). Hemolisat digunakan untuk menganalisis kadar MDA sampel, dengan teknik spektrofotometrik mengikuti prosedur Soewoto (2001).

Data absorban yang diperoleh dikalkulasi berdasarkan masing-masing parameter yang diukur :

a. Kadar MDA $=$ Profil $\operatorname{MDA}\left(\mathrm{nm} / \mathrm{M}^{-1} \mathrm{~cm}^{-1}\right)=\frac{A}{\varepsilon}$

Keterangan :

$\mathrm{A}=$ Absorban pada panjang gelombang $532 \mathrm{~nm}$

$\varepsilon=153.000 \mathrm{M}^{-1} \mathrm{~cm}^{-1}$

b. Kadar Kreatinin

$$
=\frac{\text { Abs.Sampel }}{\text { Abs,Standar }} x[\text { standar }]
$$


Kemudian dianalisis dengan teknik statistika menggunakan Uji T-Student Independent test. Dianalisis menggunakan software SPSS IBM 21.

\section{HASIL DAN PEMBAHASAN}

Berdasarkan hasil penelitian perbandingan kadar MDA dan kreatinin itik yang diberi dan tanpa pemberian minyak atsiri dalam kondisi cekaman panas, dperoleh hasil sebagai berikut :

\section{Malondialdehyde (MDA)}

Rata-rata Kadar MDA itik yang diberi dan tanpa pemberian minyak atsiri dalam kondisi cekaman panas, berdasarkan hasil penelitian rata-rata kadar MDA itik cihateup dalam kondisi terekspos panas berlebih. Tampak bahwa rata-rata kadar MDA kelompok itik yang mendapatkan minyak atsiri berbeda nyata lebih rendah $(\mathrm{P}<0,05)$ yaitu 1,436 dibandingkan tanpa pemberian minyak atsiri $(2,884)$.

Berdasarkan hasil penelitian ini dapat dikemukakan bahwa minyak atsiri dari garlic mampu berperan menanggulangi senyawa radikal sehingga menurunkan dampak peroksidasi lipid oelh senyawa radikal. Minyak atsiri juga mampu menurunkan pemanfaatan kreatin menjadi kreatinin. Hasil ini menunjukkan kemampuan atsiri untuk memperbaiki sistem pengaturan panas tubuh itik (thermoregulasi). Thermoregulasi yang cenderung normal tidak menyebabkan sintesis energy cenderung normal tampa harus melibatkan mekanisme glukoneogenesis. Diketahui bahwa peningkatan gluconeogenesis memacu peningkatan radikal bebas.

Beberapa peneltian mengajukan pengertian stres (cekaman) panas, antara lain merupakan kondisi ketidakseimbangan panas tubuh ternak dengan lingkungannya, sehingga terjadi gangguan thermoregulasi, karena suhu atau kelembaban lingkungan yang melebihi kisaran zona nyaman bagi metabolism normalnya (Austic, 2000). Itik yang sedang berada dalam kondisi stres menyebabkan sulitnya mempertahankan keseimbangan produksi dan pembuangan panas tubuhnya karena pengaruh aktivitas metabolisme, aktivitas hormonal dan kontrol suhu tubuh.

Temperatur lingkungan yang tinggi dan disertai kelembaban tinggi melebihi kisaran zona suhu nyaman memicu peningkatan stres oksidatif pada itik, dimana akan terjadi serangan radikal bebas pada membran sel. Senyawa radikal ini menyebabkan gangguan metabolit serta penurunan fungsi sel yaitu mutasi DNA, kegagalan transkripsi, kesalahan 
translasi dan fungsi protein yang menurun, sehingga menyebabkan mutasi atau sitotoksik dan perubahan laju aktivitas enzim (Kinanti, 2011), hal ini berdampak terhadap gangguan hingga penurunan metabolisme. Hasil penelitian lain menunjukkan bahwa produksi radikal bebas (Reactive Oxygen Species $=$ ROS) yang semakin tinggi seiring dengan peningkatan temperatur lingkungan, keadaan ini menjadi lebih tidak mnguntungkan bagi ternak apabila disertai dengan peningkatan kelembaban udara lingkungan kandang (Mushawwir dan Latipuddin, 2013).

Peroksidasi lipid merupakan fenomena kimiawi yang bersifat kompleks sebagai dampak terjadinya reaksi terhadap poly unsaturased fatty acid (PUFA) atau asama lemak rantai panjang ganda, penyusun fosfolipid membran sel dengan senyawa ROS, membentuk hidroperoksida yaitu MDA (Addabbo dkk., 2009). ROS adalah senyawa turunan oksigen yang lebih reaktif dibandingkan oksigen pada kondisi dasar (ground state). ROS tidak hanya terdiri dari molekul oksigen tanpa pasangan elektron seperti radikal hidroksil $(\cdot \mathrm{OH})$, radikal superoksida $\left(\mathrm{O}_{2}-\right)$, dan nitrit oksida $(\mathrm{NO} \cdot)$, tetapi juga molekul reaktif yang memiliki elektron berpasangan. Molekul oksigen yang memiliki elektron berpasangan tersebut diantaranya, hipoklorous $(\mathrm{HOCl})$, hidrogen peroksida $\left(\mathrm{H}_{2} \mathrm{O}_{2}\right)$, asam dan anion peroksinitrit (ONOO-). Target utama peroksidasi oleh ROS adalah PUFA dalam lipid membran. PUFA didegradasi oleh radikal-radikal bebas membentuk MDA. Kadar MDA dalam darah banyak digunakan sebagai indicator (penanda) kerusakan seluler akibat reaksi senyawasenyawa radikal bebas (Inoue, 2001; Chen dkk., 2009, Mushawwir dkk., 2012).

Ion $\mathrm{OH}^{-}$merupakan salah satu contoh radikal bebas yang dapat menyebabkan kerusakan hingga kematian sel (negrosis) dengan cara mengoksidasi lipid dinding sel, terutama asam-asam lemak tidak jenuh rantai panjang (poly unsaturated fatty acid/PUFA). Bottje dkk. (1995); Mujahid (2007) dan Mushawwir (2015) menunjukkan bahwa senyawa hidroksil $\left(\mathrm{OH}^{-}\right)$mampu mengekstrasi satu hidrogen dari lemak polyunsaturated (LH), sehingga terbentuklah radikal lemak (L-). Dampak peningkatan radikal bebas seiring dengan peningkatan temperature atau cekaman panas, menjadi alasan utama peningkatan MDA sebagai produk katabolisme asam lemak rantai pajang tidak jenuh (Tabel 1 dan Illustrasi 1).

Proses metabolisme di dalam tubuh dapat pula menyebabkan pembentukan radikal bebas, maka secara alami pun reaksi peroksidasi lipid dapat terjadi. Peroksidasi lipid yang dipicu oleh senyawa radikal merupakan reaksi terhadap PUFA yang mengandung sedikitnya ikatan rangkap diserang oleh radikal bebas. Peroksidasi lipid diinisiasi oleh 
radikal bebas seperti radikal anion superoksida, radikal hidroksil dan radikal peroksil. Radikal bebas secara terus menerus disintesis oleh mitokondria itik. Setiap radikal bebas yang terbentuk dalam sel hewan dapat memulai suatu reaksi berantai yang akan terus berlanjut sampai radikal bebas ini dihilangkan oleh radikal bebas lain dan oleh sistem antioksidan tubuh (endogen) atau sistem antioksidan eksogen (Allen, 2000).

Tabel 1. Rata-rata Kadar MDA Itik yang Diberi dan Tanpa Pemberian Minyak Atsiri dalam Kondisi Cekaman Panas

\begin{tabular}{cc}
\hline Kelompok Itik & Rata-rata $\left(\mathrm{nm} \cdot \mathrm{M}^{-1} \cdot \mathrm{cm}^{-1}\right)$ \\
\hline Tanpa Atsiri & $2,884^{\mathrm{a}}$ \\
Atsiri $0,5 \mathrm{~mL} \cdot \mathrm{BB}^{-1}$ & $1,436^{\mathrm{b}}$ \\
\hline $\begin{array}{c}\text { Keterangan : nilai rata-rata yang diikuti abjad yang berbeda menunjukkan perbedaan yang } \\
\text { nyata (P<0,05) }\end{array}$
\end{tabular}

Terkait dengan peran minyak atsiri, Solichadi (2002) melaporan peran minyak atsiri yang mampu bertindak sebagai antioksidan. Dengan demikina pemberian minyak atsiri kepada itik perlakuan yang mengalami cekaman panas mampu mengurangi resiko meningkatnya perosidasi lipid oleh senyawa radikal. Berdasarkan kemampuan atsiri ini menyebabkan kadar MDA pada itik yang mangalami cekaman panas menurun atau lebih rendah (Tabe 1 dan Gambar 1).

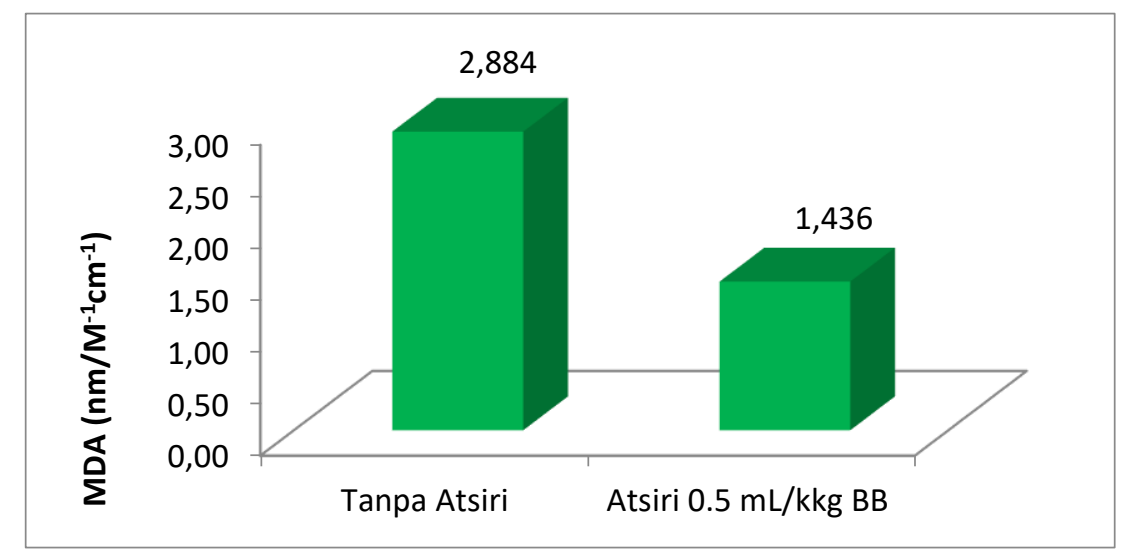

Gambar 1. Perbedaan Rata-rata Kadar MDA Kelompok Itik yang Diberi dan Tanpa Pemberian Atsiri 


\section{Kreatinin}

Rata-rata kadar kreatinin itik yang diberi dan tanpa pemberian minyak atsiri dalam kondisi cekaman panas, berdasarkan hasil penelitian disajikan pada Tabel 2.

Tabel 2. Rata-rata Kadar Kreatinin itik yang Diberi dan Tanpa Pemberian Minyak Atsiri dalam Kondisi Cekaman Panas

\begin{tabular}{cc}
\hline Kelompok Itik & Rata-rata \\
\hline Tanpa Atsiri & $5,923^{\mathrm{a}}$ \\
Atsiri $0,5 \mathrm{~mL} \cdot \mathrm{BB}^{-1}$ & $4,833^{\mathrm{b}}$ \\
\hline
\end{tabular}

Keterangan : nilai rata-rata yang diikuti abjad yang berbeda menunjukkan perbedaan yang nyata $(\mathrm{P}<0,05)$

Tabel 2 dan Illustrasi 2 menunjukkan perbedaan rata-rata kadar kreatinin itik cihateup dalam kondisi terekspos panas berlebih. Tampak bahwa rata-rata kadar kreatinin kelompok itik yang mendapatkan minyak atsiri berbeda nyata lebih rendah $(P<0,05)$ yaitu 4,833 dibandingkan tanpa pemberian minyak atsiri $(5,923)$.

Berdasarkan hasil penelitian ini dapat dikemukakan bahwa minyak atsiri dari garlic mampu berperan menanggulangi stress cekaman panas sehingga menurunkan dampak thermoregulasi yang tinggi. Minyak atsiri juga mampu menurunkan pemanfaatan kreatin menjadi kreatinin. Hasil ini menunjukkan kemampuan atsiri untuk memperbaiki sistem pengaturan panas tubuh itik (thermoregulasi). Thermoregulasi yang cenderung normal tidak menyebabkan kontraksi otot-otot pernafasan dan jatung bekerja lebih keras, dengan demikian kreatin tidak banyak digunakan sebagai sumber energi.

Peningkatan kadar kreatinin seperti yang tampak pada Gambar 1. merupakan mekanisme homoetasis cairan tubuh guna mempertahankan temperatur normal cairan ekstrasellular dan intrasellular. Peningkatan pengaliran darah ke perifer selama cekaman panas yang berkepanjangan mempunyai konsekuensi menurunkan tekanan darah arteri sebagai akibat gangguan terhadap fungsi homeostasis dari sistem kardiovaskuler (Aengwanich, 2007). Terdapat dua kemungkinan mekanisme yang ditempuh karena meningkatnya pengaliran darah keperifer, yaitu peningkatan curah jantung dan redistribusi pengaliran darah ke berbagai bagian tubuh sesuai dengan fungsi pengaturan suhu tubuh. 
Kedua mekanisme tersebut pada dasarnya berhubungan erat, yaitu melalui kontrol reflex tekanan darah arteri.

Kontraksi kardiovaskuler merupakan manifestasi dari kerja pusat pengatur suhu yang terletak di hypothalamus, apabila di dalam hypothalamus arterior dalam keadaan panas, maka pembuluh darah periferi akan mengalami dilatasi dan walaupun suhu lingkungan normal, terlihat gejala kepanasan. Perubahan suhu ini disebarkan ke seluruh tubuh diantaranya sampai di pusat pengaturan suhu tubuh. Pusat ini sangat sensitif terhadap setiap perubahan suhu darah. Ketika temperature darah meningkat menyebabkan reaksi penyesuaian ialah memperbesar semua pembuluh darah di periferi melalui pengeluaran hormon epinephrine dan norepinephrine (Tan dkk. 2010, Mushawwir dkk., 2012).

Perubahan temperatur tubuh mendapat respons Heat Regulating Center (HRC), kemudian diteruskan ke pusat simpatikus dan akan menyebabkan pengaktifan "Sympathicoadrenomedullary" dan peningkatan sekresi adrenalin dan glukortikoid. Sekresi adrenalin terutama distimulasi oleh neurotransmitter, dan glukortikoid oleh gertakan Adreno Corticotropic Hormone (ACTH) dari pituitary anterior (Dawson dan Whittow, 2000; Puvadolpirod dan Thaxton, 2000; Bohmanova dan Chikamune, 2007; Rhoads dkk., 2013).

Dampak utama cekaman panas adalah terjadinya peningkatan aktivitas, meskipun ini merupakan salah satu upaya untuk memelihara temperature tubuh itik pada tingkat yang normal. Ini terjadi karena ternak unggas tidak mempunyai kelenjar keringat untuk membuang panas melalui penguapan, dalam hal ini satu-satunya organ yang dapat melaksanakan proses penguapan secara efektif hanya alat pernafasan, maupun radiasi dan konduksi dengan udara atau media lingkungannya.

Cekaman fisiologik seperti diuraikan sebelumnya adalah manisfestasi untuk mencapai homeostasis agar metabolisme normal dapat dipertahankan. Paling tidak untuk mempertahankan metabolisme hidup pokok. Fenomena fisiologi dan biokimia ini membutuhkan energi yang banyak, apalagi untuk tetap mempertahankan produksi ternak.

Kebutuhan energi yang besar diperparah dengan menurunnya intake pakan untuk mencegah heat increament dari pencernaan pakan. Demi memenuhi kebutuhan energi ini, maka peningkatan kadar hormon ephinefrin yang disekresikan medulla adrenal, mendorong sintesis glukosa melalui glikogenolisis dengan pengaktifan siklus adenine monofosfat (cAMP). Dalam kondisi stress yang lebih berat akibat peningkatan cekaman panas, memicu sintesis ATP dari prekursor keratin fosfat menjadi kreatinin. Dalam kondisi ginjal yang 
normal maka kreatinin dapat menjadi indikasi jumlah perombakan kreatin fosfat untuk membentuk ATP (Shinder, 2007 dan Wang dkk., 2007, Mushawwir dkk, 2011 dan 2012). Hal ini dilakukan untuk memenuhi energy kontraksi otot jantung dan otot-otot terkait respirasi. Inilah sebabnya kadar kreatinin kelompok itik tampak lebih tinggi pada itik yang tanpa pemberian minyak atsiri (Gambar 2).

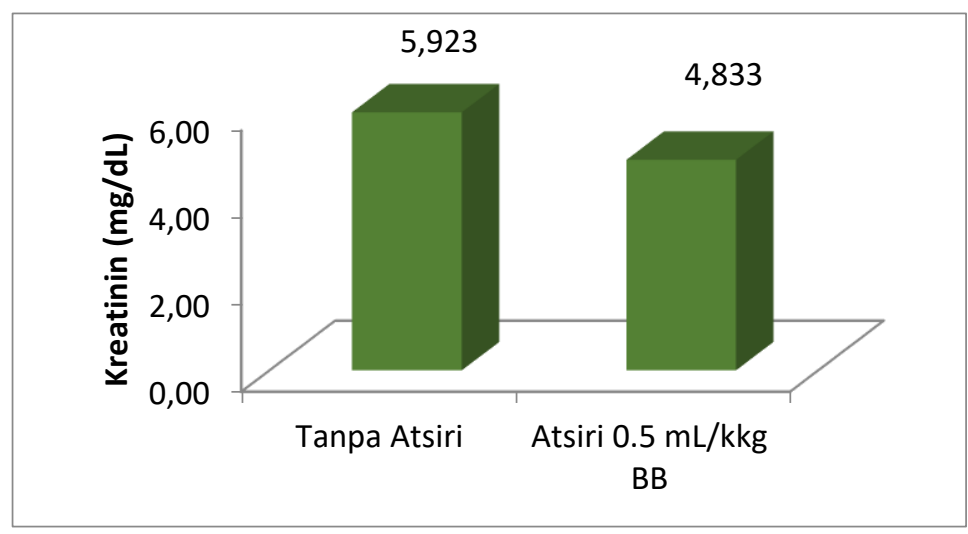

Gambar 2. Perbedaan Rata-rata Kadar Kreatinin Kelompok Itik yang Diberi dan Tanpa Pemberian Atsiri

Minyak atsiri mengandung kurang labih 14 komponen, dengan komponen utama adalah diallyl disulfide dan diallyl trisulfida. Diketahui bahwa kedua komponen aktif tersebut mampu menurunkan derajat stress ternak mellaui mekanisme penghambtannya terhadap reseptor syaraf. Dengan demikian akan menghambat sistem syaraf pusat untuk memberikan respon berlebihan terhadap panas, maka fenomena ini akan membuat ternak lebih tenang. Beberapa hasil penelitian lain menunjukkan bahwa minyak atsiri mampu menstimulan hormone penenang dan menghambat stimulasi epinefrin yang meningkatkan denyut jantung dan kontraksi otot (Mushawwir, 2015).

\section{KESIMPULAN}

Berdasarkan hasil penelitian disimpulkan bahwa minyak atsiri mampu menghambat sintesis malondialdehyde (MDA) dan kreatinin itik cihateup yang mengalami cekaman panas. 


\section{DAFTAR PUSTAKA}

Addabbo, F., Montagnani, M., and Goligorsky, M. S. 2009. Mitochondria and reactive oxygen species. Hypertension, 53, 885-892.

Aengwanich, W. 2007. Effects of high environmental temperature on blood indices of thai indigenous chickens, thai indigenous chickens crossbred and broilers. International Journal of Poultry Science,6, 427-430.

Allen R.G. 2000. Tressini M. Oxidative stress and gene regulation. Free Radical Biol Med. 28:463-99.

Bohmanova, K., and Chikamune, T. 2007. Comparison of Physiological Response to the Environments in Swamp Buffalo and Cattle Under a Temperate Condition. Dalam : H. Shimizu (Editor) Current Development and Problems in Swamp Buffalo Production. Proceedings of the Preconference Symposium of the $5^{\text {th }}$ World Conference on Animal Production, Tsukuba. Japan: 107 - 127.

Bottje, W., Enkvetchakul, B., \& Moore, R, 1995. Effect of a-tocopherols on antioxidants, lipid peroxidation, and the incidence of pulmonary hypertensio syndrome (ascites) in broilers. Poultry Science, 74, 1356-1369.

Dawson, W.R., and Whittow, G.C. 2000. Regulation of Body Temperature, in Sturkie's Avian Physiology, $5^{\text {th }}$ ed., edited by Whittow, G.C.Academic Press, Elsevies Sci.Pub.Co., Sydney.

Soewoto, H., Sadikin, M., Kurniati, V., Wanandi, S.I. G.R., Dwirini. S.P., Abadi. Prijanti, R.A., Harahap, P.I., dan Jusman, A.W.S. 2001. Biokimia Eksperimen Laboratorium. Widya Medika, Jakarta

Solichadi. K. 2002. Pemanfaatan Kunyit (Curcuma domestika VAL) dalam Ransum Broiler Sebagai Upaya Menurunkan Lemak Abdominal dan kadar Kolesterol. Jurnal Pengembangan Peternakan Tropis Fakultas Peternakan Universitas Diponegoro, 27.

Inoue M. 2001. Protective Mechanisms Against Reactive Oxygen Species. In Arias IM The Liver Biology and Pathobiology LJippincott Williams and Wilkins 4th-ed. Philadelphia.

Kinanti, A.S.2011. Pengaruh suplementasi vitamin E dan DL methionine dalam ransum terhadap performa ayam broiler pada kondisi cekaman panas. Skripsi. Departemen Ilmu Nutrisi dan Teknologi Pakan, Fakultas Peternakan, Institut Pertanian Bogor, Bogor.

Mujahid, A., Akiba, Y., \& Toyomizu, M.. 2007. Acute heat stress induces oxidative stress and decreases adaptation in young white leghorn cockerels by down regulation of avian uncoupling protein. Poultry Science, 86, 364-371.

Mushawwir, A. dan Latipudin, D. 2011. Beberapa parameter biokimia darah ayam ras petelur fase grower dan layer dalam lingkungan "upper zonathermoneutral". Jurnal Peternakan Indonesia, 13 (3) : 191-198.

Mushawwir, A. dan Latipudin. D.2012. Respon fisiologi thermoregulasi ayam ras petelur fase grower dan layer. Proceeding of National Seminar on Zootechniques, 1(1), 23-27.

Mushawwir A. dan D. Latipuddin. 2013. Biologi Sintesis Telur, Perspektif Fisologi, Biokimia dan Molekuler Produksi Telur. Penerbit Graha Ilmu, Yogyakarta.

Mushawwir, A. 2015. Biokimi Nutrisi. Widya Padjadjaran, Bandung.

Puvadolpirod, S. And Thaxton, J.P. 2000. Model of physiological stress in chickens 1. Response parameters. Poultry Science, 79, 363-369. 
A. Mushawwir dkk., 11 JiiP Volume 5 Nomor 1: 1-11, Juni 2019

Rhoads, R.P., Baumgard, L.H., and Suagee, J. K. 2013. Metabolic priorities during heat stress with an emphasis on skeletal muscle. Journal Animal Science, 91, 2492-2503.

Shinder, D., Rusal, M., Tanny, J., Druyan, S., and Yahav, S. 2007. Thermoregulatory responses of chicks (gallus domesticus) to low ambient temperatures at an early age. Poultry Science, 86, 2200-2209.

Tan, G.Y., Yang , L., Y.-Q. Fu , Feng, J.H., and Zhang, M.H. 2010. Effects of different acute high ambient temperatures on function of hepatic mitochondrial respiration, antioxidative enzymes, and oxidative injury in broiler chickens. Poultry Science. 89, 115-122.

Wang, S. C., Chen, J., Huang, Y., Li, X.F., and Zhang, D.J. 2007. Effect of heat stress on production performance and blood biochemical indices in broiler. China Poultry, 15, 11-13. 